\title{
Patogenisitas Cendawan Entomopatogen dari Rizosfir Kacang Tanah (Arachis hypogaea Linnaeus) terhadap Hama Penggerek Polong Etiella zinckenella Treitschke (Lepidoptera: Pyralidae)
}

\section{Pathogenicity of Entomopathogenic Fungi from Peanut Rhizosphere (Arachis hypogaea Linnaeus) to Pod Borer Etiella zinckenella Treitschke (Lepidoptera: Pyralidae)}

\author{
Faridwan Amri $^{1)}$, Martinius ${ }^{2)}$ dan Reflinaldon ${ }^{2) *}$
}

1) Program Studi Agroteknologi Fakultas Pertanian Universitas Andalas Padang

2) Program Studi Proteksi Tanaman Fakultas Pertanian Universitas Andalas Padang

E-mail: donsyukur@gmail.com

\begin{abstract}
The objective of this study was to get entomopathogenic fungi isolates of bean plant rhizosphere derived from Nagari Sawah Tangah, District Pariangan, Tanah Datar Regency and to determine their pathogenicity on pod borer E. zinckenella. Isolation method was performed by diluting the soil samples in a serial dilution into $10^{-3}$ and cultured in PDA media. Furthermore, the purification was based on the shape and color of the fungus colonies. A total of 16 isolates obtained at the initial stage were selected by testing them against the fifth instar larvae Tenebrio molitor. Results showed that only 4 isolates (STA 1, STA 2.2, STA 5, and STB 3.1) could be further tested against E. zinckenella pod borer using completely randomized design (CRD). The highest pathogenicity isolates was exhibited by STA 1 belonged to Metarhizium genera.
\end{abstract}

Keywords: Peanut, Etiella zinckenella, Entomopathogenic fungi

\section{PENDAHULUAN}

Etiella zinckenella Treitschke (Lepidoptera: Pyralidae) adalah salah satu hama berpengaruh besar terhadap penurunan produksi kacang tanah. Hama ini dulunya diketahui hanya menyerang tanaman kedelai (Kalshoven, 1981). Perubahan kondisi lingkungan menyebabkan terjadinya pergeseran tanaman inang E. zinckenella yang semula adalah kedelai, kemudian juga dapat beradaptasi pada kacang tanah (Hamid et al., 2012).

E. zinckenella dilaporkan menyerang kacang tanah di Bengkulu yang menyebabkan gagal panen (Apriyanto et al., 2008). Berdasarkan survei awal yang dilakukan pada tahun 2010 di Kabupaten
Pasaman Barat, E. zinckenella juga menyerang tanaman kacang tanah dengan tingkat serangan mencapai $70-80 \%$ (Obel, 2012). Hal yang sama juga terjadi di Kabupaten Tanah Datar (Komunikasi pribadi, Ketua Balai Penyuluhan Pertanian, 2014).

Teknologi pengendalian yang sedang dikembangkan dan banyak dilakukan oleh para peneliti adalah dengan memanfaatkan agens hayati seperti entomopatogen. Dua jenis cendawan entomopatogen yang sudah dilaporkan efektif untuk pengendalian berbagai jenis hama adalah Beauveria bassiana (Balsamo) dan Metarhizium anisopliae var. anisopliae. Kedua cendawan ini efektif mengen- 
dalikan Plutella xylostella (Pujiastuti, 2006; Nunihlawati et al. 2012), ulat krop kubis Crocidolomia pavonana (Trizelia, 2005; Nuraida, 2006), ulat grayak Spodoptera litura (Prayogo et al., 2005), dan hama penggerek buah kakao (PBK) Conopomorpha cramerella (Trizelia et al., 2013).

Hasyim et al. (2009) menjelaskan bahwa cendawan entomopatogen yang virulen dapat diperoleh dari hama target atau dari rizosfir pada ekosistem pertanaman dimana hama tersebut berada, karena tanah merupakan reservoar alami bagi cendawan entomopatogen. Meyling dan Eilenberg (2007) melaporkan cendawan entomopatogen yang berhasil diisolasi dari tanah antara lain dari genus Beauveria, Isaria (Cordycipitaceae) dan Metarhizium (Clavicipitaceae). Selanjutnya Rishi et al. (2013) berhasil mengisolasi 6 jenis cendawan dari larva Galleria mellonella antara lain: Fusarium oxysporum, Aspergillus flavus, B. bassiana, M. anisopliae, Fusarium sp., dan Paecilomyces sp. Penelitian ini bertujuan untuk mengetahui keanekaragaman cendawan entomopatogen yang terdapat di rizosfir kacang tanah yang berpotensi mengendalikan E. zinckenella di lapangan.

\section{METODOLOGI}

Penelitian ini telah dilaksanakan pada bulan September sampai November 2014 di Laboratorium Pengendalian Hayati Fakultas Pertanian Universitas Andalas.

\section{Seleksi cendawan entomopatogen}

Pengoleksian cendawan menggunakan metode eksplorasi yaitu dengan mengambil sampel dari tanah perakaran kacang tanah di sentra produksi kacang tanah di Nagari Sawah Tangah Kabupaten Tanah Datar. Sekitar $500 \mathrm{~g}$ tanah diambil di sekitar perakaran kacang tanah setelah digali sedalam $10-15 \mathrm{~cm}$, pada 10 titik sampel yang terdapat di dua lokasi.
Tanah sampel dimasukkan ke dalam kantong plastik, diberi label dan disimpan dalam kotak pendingin (box cooler). Sampel kemudian dibawa ke laboratorium dan diisolasi menggunakan metode pengenceran (Hamid et al., 2012).

Isolasi dilakukan secara aseptis di ruangan lemari asam dengan mengambil 10 gram dari masing-masing sampel tanah, lalu dimasukkan dalam $100 \mathrm{ml}$ akuades steril yang telah diberi larutan agristik dalam gelas erlenmeyer $250 \mathrm{ml}$ dan dihomogenkan dengan vortex selama 2 menit. Suspensi tanah diencerkan (serial dilution) sampai $10^{-3}$ dan $0,1 \mathrm{ml}$ suspensi dimasukkan dalam cawan petri kaca yang telah berisi media PDA dan diinkubasi selama 2-4 hari.

Setelah ada cendawan yang tumbuh, selanjutnya dilakukan pemurnian berdasarkan bentuk dan warna koloni yang berbeda dengan cara di potong 1x1 $\mathrm{cm}$ pada cendawan yang tumbuh lalu dipindahkan pada cawan petri dengan media PDA hingga didapatkan koloni cendawan yang benar-benar murni.

Cendawan lalu diperbanyak dalam media PDA dengan cara menumbuhkan potongan cendawan rizosfir yang berdiameter $0,8 \mathrm{~cm}$ dengan menggunakan cork borer dan diinkubasi pada suhu ruang selama 15 hari.

\section{Penyiapan cendawan uji}

Pengujian menggunakan larva $T$. molitor instar $\mathrm{V}$ dengan cara memasukkan larva T. molitor sebanyak 40 ekor pada media PDA yang berisi biakan cendawan hasil isolasi. Larva dibiarkan pada media biakan selama 24 jam agar terjadi kontak antara konidia dengan serangga. Kemudian 10 ekor larva dipindahkan ke dalam petri plastik berdiameter $9 \mathrm{~cm}$ dan diberi makan berupa pelet ikan. Pengamatan terhadap larva yang terinfeksi cendawan (sporulasi) dilakukan selama 7 hari setelah aplikasi. 
Larva yang terinfeksi disterilisasi permukaan dengan merendam pada akuades selama 1 menit, alkohol 70\% selama 1 menit dan dimasukkan kembali pada akuades selama 1 menit lalu dikeringanginkan dengan kertas saring steril. Larva dimasukkan ke dalam cawan petri yang telah berisi kertas tisu lembab steril dan diinkubasi untuk merangsang pertumbuhan cendawan entomopatogen. Konidia cendawan yang tumbuh diambil dengan jarum ose dan dipindahkan ke dalam cawan petri yang telah berisi media PDA sampai diperoleh biakan murninya. Isolat yang telah murni, diisolasi dan diperbanyak pada media SDAY sebagai sumber cendawan entomopatogen untuk pengujian hama target (larva instar V) $E$. zinckenella.

Konidia cendawan dipanen dengan cara menambahkan $5 \mathrm{ml}$ akuades steril dan larutan agristik sebagai bahan perata ke dalam cawan petri dan konidia dilepas dari media dengan kuas halus. Suspensi disaring dan konsentrasi konidia dihitung di bawah mikroskop dengan bantuan haemo-cytometer.

\section{Pemeliharan serangga uji}

Larva E. zinckenella diperoleh dari lapangan (kacang giring-giring), dipelihara dalam kotak dan diberi makan polong kacang giring-giring yang masih muda, yang diperoleh di sekitar Limau Manih Padang. Bagian atas kotak plastik ditutup dengan kain kassa. Ketika larva memasuki masa prapupa, larva dipindahkan ke kotak plastik yang berisi serbuk gergaji dan ditutup dengan kain kassa dan dibiarkan sampai terbentuk imago.

Imago dipindahkan ke dalam kurungan serangga dan diberi beberapa polong kacang giring-giring sebagai tempat peletakan telur bagi imago betina, dan $10 \%$ madu yang diberikan dengan kapas dan diletakkan di atas kurungan kain kasa. Telur yang dihasilkan imago, dipelihara sampai instar V.

\section{Pengujian}

Inokulasi cendawan entomopatogen pada larva E. zinckenella instar $\mathrm{V}$ dilakukan dengan cara menyemprotkan suspensi cendawan menggunakan hand sprayer yang berisi suspensi konidia pada konsentrasi $10^{8}$ konidia/ml secara merata pada tubuh larva. Jumlah larva yang diperlakukan untuk setiap satuan percobaan adalah 10 ekor larva.

Larva dimasukkan ke dalam kotak plastic yang telah diberi polong kacang giring-giring sebagai pakan. Pakan ini diganti setiap hari untuk menjaga kadar air dan kesegarannya. Setelah itu kotak plastik ditutup dengan kain kassa. Untuk perlakuan kontrol, larva E. zinckenella instar $V$ disemprot dengan akuades steril yang telah ditambah dengan satu tetes larutan agristik.

\section{Uji patogenisitas cendawan terseleksi}

Isolat cendawan yang menunjukkan sporulasi (munculnya miselia cendawan) pada tubuh larva kemudian diuji lanjut patogenisitasnya terhadap larva $E$. zinckenella instar $\mathrm{V}$ menggunakan Rancangan Acak Lengkap (RAL) yang terdiri dari perlakuan sebanyak isolat yang telah diseleksi, masing-masing dengan 3 ulangan.

\section{Pengamatan dan analisis data}

Pengamatan meliputi: identifikasi cendawan entomopatogen, mortalitas larva, persentase pupa yang terbentuk, persen-tase imago yang terbentuk, efektivitas perlakuan, dan laju pertumbuhan diameter koloni cendawan.

Identifikasi dilakukan secara makroskopis dan mikroskopis. Pengamatan makroskopis cendawan dilakukan secara visual terhadap warna, bentuk dan arah pertumbuhan koloni saat biakan cendawan entomopatogen berumur \pm 15 hari setelah inkubasi dalam media PDA. Pengamatan secara mikroskopis meliputi pengamatan terhadap percabangan konidiofor dan bentuk konidia cendawan. 
Amri F. Et al. Patogenisitas Cendawan Entomopatogen

laju pertumbuhan diameter koloni :

Rumus yang digunakan adalah:

Mortalitas larva:

$$
M=\frac{a}{b} \times 100
$$

Keterangan:

$M=$ Mortalitas larva uji (\%)

$\mathrm{a}=$ Jumlah larva uji yang mati

b = Jumlah keseluruhan larva uji (10 ekor)

Persentase peningkatan mortalitas:

$$
P M=\frac{P-K}{P} \times 100
$$

Keterangan:

PM = Peningkatan mortalitas (\%)

$\mathrm{P}=$ data pengamatan pada perlakuan

$\mathrm{K}=$ data pengamatan pada kontrol

Persentase pupa terbentuk:

$$
P=\frac{c}{b} x 100
$$

\section{Keterangan:}

$\mathrm{P}=$ Persentase pupa terbentuk (\%)

$\mathrm{C}=$ Jumlah larva yang berhasil menjadi pupa

b = Jumlah keseluruhan larva uji (10 ekor)

Persentase imago terbentuk:

$$
I=\frac{d}{b} x 100
$$

Keterangan:

$\mathrm{I}$ = Persentase imago terbentuk (\%)
$C=$ Jumlah larva yang berhasil menjadi imago

$B=$ Jumlah keseluruhan larva uji (10 ekor)

Persentase penekanan pupa dan imago terbentuk:

$$
E=\frac{K-P}{K} x 100
$$

Keterangan:

$\mathrm{E}=$ Efektivitas penekanan (\%)

$\mathrm{P}=$ data pengamatan pada perlakuan

$\mathrm{K}=$ data pengamatan pada kontrol

\section{HASIL}

\section{Seleksi isolat cendawan entomopatogen} Diperoleh 16 isolat cendawan pada rizosfir kacang di Nagari Sawah Tangah Kec.Pariangan Kab.Tanah Datar, yang terdiri dari genus Metarhizium (isolat STA 1, STA 5 dan STB 3.1) dan genus Trichoderma isolat STA 2.2. (Gambar 1). Semua isolat diseleksi dengan menguji patogenesitasnya terhadap larva Tenebrio molitor.

Hasil penelitian menunjukkan bahwa terjadi mortalitas atau kematian dari larva $T$. molitor yang beragam, mulai dari $0 \%$ sampai $100 \%$. Mortalitas tertinggi terjadi pada larva yang diberi isolat STA 5 dan STB 3.1 (100\%). Dua isolat lainnya yang menyebabkan mortalitas larva diatas $50 \%$ adalah STA 1 dan STA 2.2 (Tabel 1). 

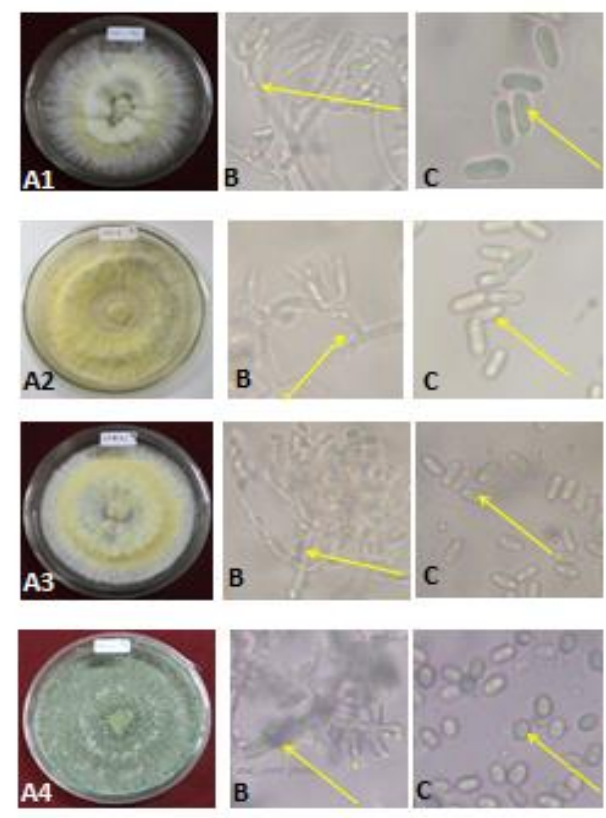

Gambar 1. Bentuk makroskopis dan mikroskopis isolat Metarhizium dan Trichoderma. A1(STA 1), A2 (STA 5), A3 (STA 3.1), A4 (STA 2.2); makroskopis cendawan secara utuh, B. Mikroskopis konidiofor dan C. Mikroskopis konidia.

Tabel 1. Mortalitas dan sporulasi larva T. molitor setelah inokulasi cendawan rizosfir

\begin{tabular}{clrc}
\hline No. & Perlakuan Isolat & Mortalitas larva (\%) & Sporulasi \\
\hline 1 & Kontrol & 10,0 & - \\
2 & STA 1 & $\mathbf{8 7 , 5}$ & + \\
3 & STA 2.1 & 20,0 & - \\
4 & STA 2.2 & $\mathbf{5 0 , 0}$ & + \\
5 & STA 3 & 0 & - \\
6 & STA 4.1 & 25,0 & - \\
7 & STA 4.2 & 15,0 & - \\
8 & STA 5 & $\mathbf{1 0 0 , 0}$ & + \\
9 & STB 1 & 0 & - \\
10 & STB 2.1 & 27,5 & - \\
11 & STB 2.2 & - \\
12 & STB 3.1 & 0 & + \\
13 & STB 3.2 & $\mathbf{1 0 0 , 0}$ & - \\
14 & STB 3.3 & 17,5 & - \\
15 & STB 4.1 & 25,0 & - \\
16 & STB 4.2 & 12,5 & - \\
17 & STB 5 & 0 & - \\
\hline
\end{tabular}

Keterangan : Angka yang ditebalkan adalah isolat dengan mortalitas tinggi dan mampu bersporulasi pada tubuh larva. + = ada, - = tidak ada.

\section{Uji patogenisitas}

Mortalitas larva

Inokulasi isolat cendawan entomopatogen meningkatkan mor-talitas larva E. zinckenella dengan persentase peningkatan mortalitas sebesar 150,04 $275,09 \%$. Tidak ada pengaruh perbedaan antar isolat terhadap mortalitas larva (Tabel 2). 
Amri F. Et al. Patogenisitas Cendawan Entomopatogen

Tabel 2. Mortalitas larva E. zinckenella (5 hari setelah perlakuan)

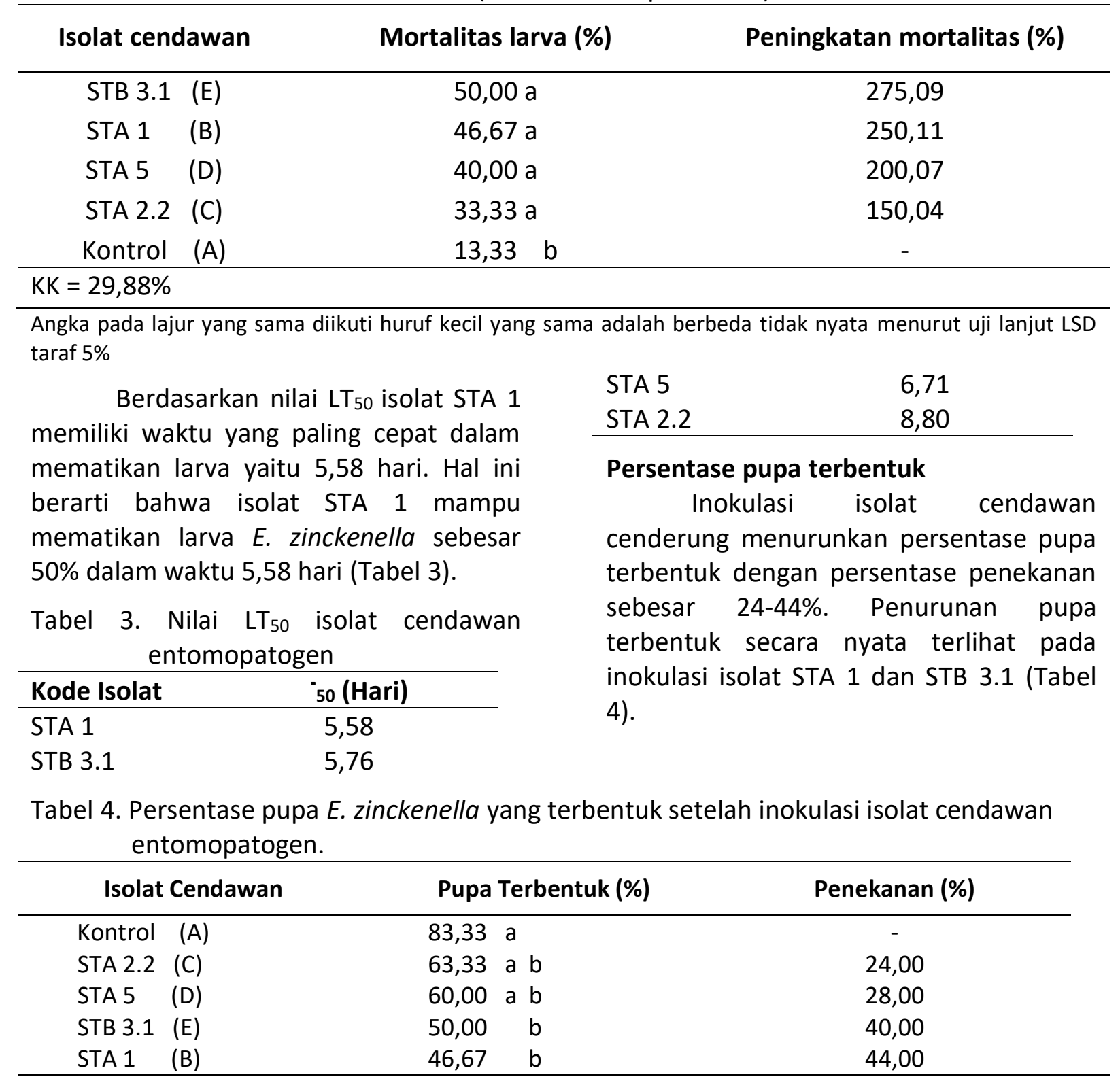

$\mathrm{KK}=22,11 \%$

Angka pada lajur yang sama diikuti huruf kecil yang sama adalah berbeda tidak nyata menurut uji lanjut LSD taraf $5 \%$.

\section{Persentase imago terbentuk}

Inokulasi isolat cendawan menurunkan persentase imago terbentuk dengan persentase penekanan sebesar 25
- 66,66\%. Penurunan persentase imago terbentuk yang paling tinggi terjadi pada inokulasi isolat STA 5, STB 3.1, STA 1 (Tabel 5).

Tabel 5.Persentase imago E. zinckenella yang terbentuk setelah inokulasi isolat cendawan entomopatogen.

\begin{tabular}{cccccc}
\hline \multicolumn{2}{c}{ Isolat Cendawan } & \multicolumn{2}{c}{ Imago Terbentuk (\%) } & Penekanan (\%) \\
\hline Kontrol & (A) & 80,00 & a & - \\
STA 2.2 & (C) & 60,00 & b & 25,00 \\
STA 1 & (B) & 33,33 & c & 58,34
\end{tabular}


Amri F. Et al. Patogenisitas Cendawan Entomopatogen

\begin{tabular}{ccccc} 
STB 3.1 & (E) & 30,00 & C & 62,50 \\
STA 5 & (D) & 26,67 & C & 66,66 \\
\hline
\end{tabular}

KK $=18,62 \%$

Angka pada lajur yang sama diikuti huruf kecil yang sama adalah berbeda tidak nyata menurut uji lanjut LSD taraf $5 \%$.

\section{Laju pertumbuhan koloni cendawan}

Dari 4 isolat yang diuji, isolat STA 2.2 merupakan isolat yang paling cepat pertumbuhan koloninya dibandingkan lainnya. Sejak mulai hari ke-1 pertumbuhan koloninya telah mencapai $1,5 \mathrm{~cm}$ dan terus bertambah dengan cepat. Pada hari ke-5 pertumbuhan koloni

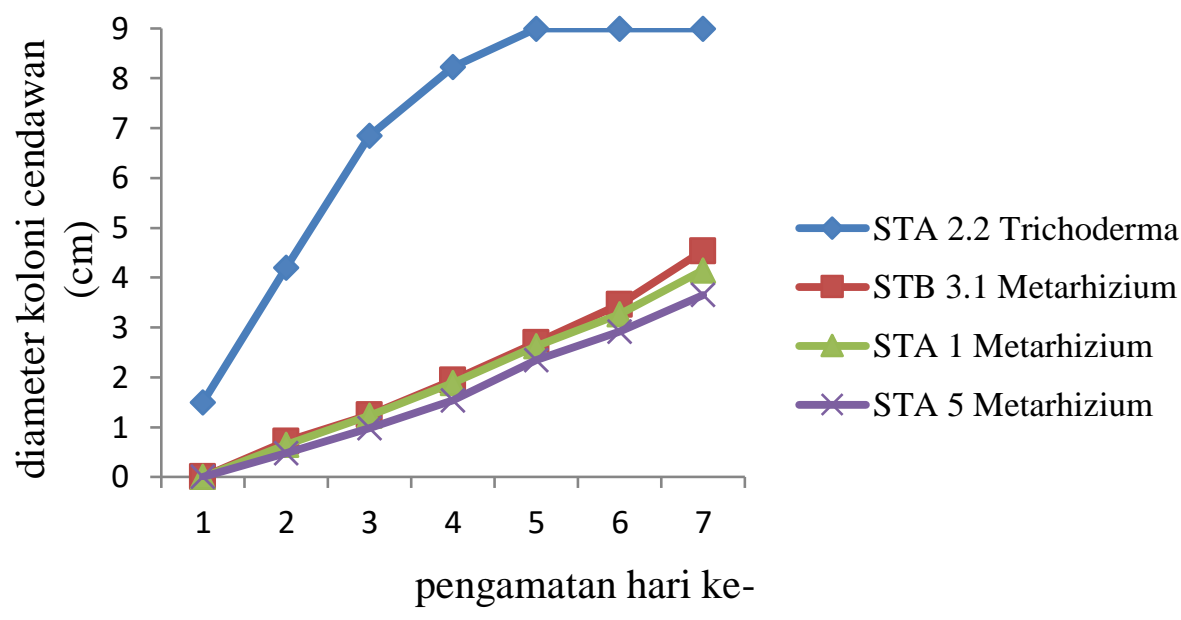

Gambar 2. Grafik rata - rata diameter koloni isolat cendawan entomopatogen setelah 1-7 hari masa inkubasi.

\section{PEMBAHASAN}

Hasil koleksi cendawan dari rizosfir kacang tanah diperoleh 16 isolat cendawan dengan karakter morfologi yang beragam. Keragaman tersebut berkaitan erat dengan kondisi tanah seperti kandungan air tanah, bahan organik tanah dan lain-lain. Hal ini sesuai dengan pernyataan Ekesi et al., (2003) yang menjelaskan bahwa keragaman cendawan rizosfir dipengaruhi oleh kandungan air tanah, tingginya bahan organik tanah dan suhu rendah.

Setiap isolat dapat meningkatkan mortalitas larva dibandingkan kontrol, namun tidak ada pengaruh perbedaan antar isolat terhadap mortalitas larva (Tabel 2). Kematian larva yang beragam cendawan telah memenuhi cawan petri yaitu $9 \mathrm{~cm}$. Sedangkan pada isolat STA 3.1, STA 1 dan STA 5 pertumbuhan koloni hampir sama. Dengan pertumbuhan maksimal pada hari ke-7 baru mencapai 4 $\mathrm{cm}$ untuk ketiga isolat tersebut (Gambar 2). 
et al. (2006) cit Budi et al. (2013) termasuk kategori patogenisitas sedang.

Berdasarkan LT 50, maka isolat STA 1 tergolong yang terbaik (Tabel 3). Hasil pengamatan ini berbeda dengan yang dilaporkan oleh Nunihlawati et al. (2012) yang mendapatkan nilai $\mathrm{LT}_{50}$ terendah yaitu 2,26 hari dan tertinggi 3,86 hari pada beberapa isolat Metarhizium. Salah satu factor yang menyebabkan perbedaan tersebut adalah penggunaan stadia larva. Trizelia (2005) menyatakan bahwa stadia perkembangan serangga juga mempengaruhi keberhasilan penggunaan cendawan entomopatogen.

Isolat yang berhasil menurunkan pupa terbentuk secara nyata adalah STA 1 dan SB 3.1 (Tabel 4). Sementara itu, isolat yang berhasil menurunkan imago terbentuk paling tinggi adalah STA 5, STB 3.1 dan STA 1 (Tabel 5).

Rendahnya persentase pupa terbentuk pada isolat STA 1 (Metarhizium) karena cendawan memiliki toksin yang menghambat pembentukan pupa. Tanada \& Kaya (1993) mengemukakan, Metarhizium spp. menghasilkan toksin yaitu destruksin yang bisa membunuh serangga inang dengan merangsang atau memacu terjadinya kerusakan jaringan serangga, kehilangan keutuhan struktural membran dan kemudian terjadi dehidrasi. Di samping itu, kegagalan larva membentuk pupa juga mempengaruhi pembentukan pupa. Pupa yang terbentuk dengan kondisi abnormal memiliki ukuran lebih kecil, per-mukaannya lebih keriput dan gelap, lembek jika ditekan dan akan muncul hifa atau miselia jika terinfeksi cendawan setelah beberapa hari pupa terbentuk.

Kurnia (1998) menjelaskan bahwa larva yang terinfeksi pada tahap awal mempunyai peluang untuk lolos menjadi pupa, tetapi pada tahap selanjutnya dapat menimbulkan kematian. Cendawan entomopatogen menghasilkan toksin yang dapat merusak secara langsung fungsi tubuh terutama dalam pembentukan hormon, yaitu hormon pergantian dan pembentukan kulit (Samsinokova, 1968 cit Kurnia, 1998).

Laju pertumbuhan koloni menunjukkan isolat STA 2.2 (Trichoderma) merupakan isolat yang paling cepat partumbuhan koloninya dibandingkan dengan isolat yang lainnya. Hal ini sesuai dengan karakteristik cendawan Trichoderma yang memiliki pertumbuhan dan daya kolonisasi yang cepat dan juga karena kandungan nutrisi yang ada pada media SDAY sesuai untuk pertumbuhan koloni. Pada isolat Metarhizium (STA 1, STA 5 dan STB 3.1) pertumbuhan koloninya relatif lambat. Penelitian yang dilakukan oleh Nuraida dan Hasyim (2009) menunjukkan bahwa diameter koloni cendawan Metarhizium baru mencapai $3,21 \mathrm{~cm}$ setelah 7 hari pengamatan pada media SDAY.

Mortalitas yang tinggi oleh isolat STB 3.1 (Metarhizium) disebabkan karena cendawan Metarhizium memproduksi toksin dan senyawa enzim yang dapat mematikan larva. Saat terjadi kontak antara propagul cendawan dengan tubuh serangga cendawan $M$. anisopliae menghasilkan senyawa mukopolisakarida (Feron, 1985). Senyawa enzim yang dikeluarkan oleh $M$. anisopliae yaitu lipase, kitinase, amilase, proteinase, pospatase, dan esterase saat proses invasi dan penetrasi berlangsung (Lee dan Hou 1989; Freimoser et al. 2003 cit Prayogo et al. 2005). M. anisopliae juga menghasilkan racun cylopeptida, destruxin, dan desmethyldestruxin yang memiliki aktifitas larvasidal terhadap larva (Mittler, 1994 cit Widiyanti dan Muyadihardja, 2004).

\section{KESIMPULAN}

Ditemukan 4 isolat cendawan yang bersifat entomopatogen dari rizosfir kacang tanah di Kecamatan Pariangan 
yaitu isolat STA 1, STA 2.2, STA 5 dan STB 3.1. Isolat STA 1 (Metarhizium) tergolong isolat terbaik berdasarkan nilai peningkatan mortalitas larva, LT50, persentase pupa dan imago terbentuk.

\section{DAFTAR PUSTAKA}

Apriyanto $D$, Sriwidodo dan Priyatiningsih. 2008. Incidence of soybean pod borer on groundnut (Arachis hypogea L.). Jurnal Akta Agrosia 11(1): 41-46.

Hamid H, Reflinaldon dan Trizelia. 2012. Teknologi pengendalian hama penggerek polong kacang tanah berbasis varietas tahan dan penggunaan agens hayati. [Laporan Akhir Penelitian Unggulan Perguruan Tinggi]. Fakultas Pertanian. Universitas Andalas. Padang.

Hasyim A, Nuraida dan Trizelia. 2009. Patogenisitas jamur entomopatogen terhadap stadia telur dan larva hama kubis Crocidolomia pavonana Fabricius. Jurnal Hortikultura 19(3): 334-343.

Kalshoven LGE. 1981. The pest of crops in Indonesia. Revisi oleh P.A Van der Laan. Jakarta PT. Ichtiar Baru-Van Hoeve. Terjemahan De Plagen van de Cultuurgewassen in Indonesie.

Meyling N dan J Eilenberg. 2007. Ecology of the entomo-pathogenic fungi Beauveria bassiana and Metarhizium anisopliae in temperate agro-ecosystems: Potential for Conservation Biological Con-trol. Biological Control 43: 145155.

Obel. 2012. Tingkat Ketahanan beberapa varietas kacang tanah (Arachis hypogaea L.) terhadap hama penggerek polong Etiella zincknella Treit. (Lepidoptera: Pyralidae) di Kabupaten Pasaman Barat. [Skripsi].
Fakultas Pertanian. Universitas Andalas. Padang.

Prayogo $\mathrm{Y}$, Tengkano dan Marwoto, W. 2005. Prospek cendawan entomopatogen $M$. anisopliae untuk mengendalikan ulat grayak Spodoptera litura pada kedelai. Jurnal Litbang Pertanian 24 (1): 1926.

Rishi RR, RK Borah, R Kumar dan S Pandey. 2013. Isolation, identification and mass production of soil microbes and their utility for biocontrol. International Journal of Advanced Life Sciences 6(3): 168-173.

Trizelia, Nurbailis dan D Ernawati. 2013. Virulensi berbagai isolat jamur entomopatogen Metarhizium spp. terhadap hama penggerek buah kakao Conopomorpha cramerella snell. (Lepidoptera: Gracil-lariidae). Jurnal HPT Tropika 13 (2): 151-158.

Trizelia. 2005. Cendawan Entomo-patogen B.bassiana, keragam-an genetik, karakter fisiologi dan virulensi terhadap Croccidolomia pavonana. [Disertasi]. Institut Pertanian Bogor. Bogor. 